\title{
Secondary Metabolites Investigation and TLC Analysis of Leaves, Stem Back and Root Extracts of Uvaria Chamae (UDAGU)
}

\author{
Ogbuanu, C.C. Amujiogu, S.N. Agboeze Emmanuel \\ Department of Industrial Chemistry, Enugu State University of Science and Technology, Enugu Nigeria. \\ P.M.B. 01660, Enugu, Nigeria
}

\begin{abstract}
Secondary metabolites in a plant materials are known to be responsible for the physiological, pharmaceutical and medicinal activities of a plant. This study therefore aimed to screen for the secondary metabolites responsible for the traditional use of Uvaria chamae (Udagu) in Oghe traditional medicine. Three solvents of increasing polarity were successively used to exhaustibly extract the secondary metabolites present. Simple chemical tests were employed to screen for the secondary metabolites in the extracts. The result of the analysis revealed the presence of saponins, tannins, flavonoids, alkaloids and carbohydrates in the leaves; saponins, tannins, flavonoids, alkaloids and carbohydrates in the stem back and saponins, tannins, anthracenes, flavonoids, alkaloids, carbohydrates and protein in the root. The presence of anthracene only in the root may be working in synergy with other secondary metabolites and probably justifying the use of root in traditional medicine.
\end{abstract}

Keywords: Secondary metabolites; Uvaria chamae; Successive extraction; thin layer chromatographic analysis; Leaves, Stem back and Root; anthracene.

DOI: $10.7176 / \mathrm{JNSR} / 10-10-05$

Publication date:May $31^{\text {st }} 2020$

\section{Introduction}

The known richest resource of drugs, nutrients, food supplements, folk medicines, pharmaceutical intermediates and chemical entities for synthetic drugs are plants (Hammer et al., 1999). Plants extracts either as pure compounds or as standardized extracts provide unlimited opportunities for new drugs discoveries because of the unmatched availability of chemical diversity (Cosa et al., 2006).

The use of plants and plant products as medicines could be traced as far back as the beginning of human civilizations and traditional medicines are relied upon by the world's population for their primary health care needs. Benin, India, Rwanda, Tanzania, Uganda, Canada, Australia, France, USA, Belgium and Ethiopia use traditional medicine $90 \%$ 70\% 70\% 70\% 60\% 60\% 70\% 48\% 49\% 42\% 31\% respectively (WHO, 2002; Zhang, 2004) (being accessible and affordable) to help meet their primary health care needs.

Secondary metabolites are referred to a wide variety non-nutritive compounds made by plants for purposes such as disease and pathogen defense and control but may (display different biological activities such as: antioxidant, anti-inflammatory, anti-cancer and anti-bacterial properties) affect human health (Kumar et al., 2013).

Nature provides $80 \%$ of all pharmacological and therapeutic lead compounds and the National Cancer Institute (NCI) estimates that over $60 \%$ of the compounds currently in pre-clinical and clinical development in its laboratories are of natural origin. Thus, higher plants remain an important and reliable source of potentially useful chemical compounds not only for direct use as drugs, but also as unique prototypes for synthetic analogues and as tools that can be used for a better understanding of biological processes (Farnsworth,1984).

$U$. chamae belongs to the family of Annonaceae also called the custard apple family and is a climbing large shrub or small tree of about 4.5 meters high, native to tropical West and Central Africa where it grows in wet and dry forests and coastal scrublands. The family is concentrated in the tropics, with few species found in temperate regions. About 900 species are Neotropical, 450 are Afrotropical, and the other species Indomalayan (Chatroui et al., 2012; Subramanion et al., 2013). It is called "Mmimi ohia" or Udagu, "Kas kaifi", and "Akisan" amongst the Ibo, Hausa and Yoruba of Nigeria respectively. The fruits are yellow when ripe and have a sweet pulp which is widely eaten. All parts of the Annonaceae plants exhibits aromatic fragrant and among them only four genera, Annona, Rollinia, Uvaria and Asimina produce edible fruits.

Extracts from the family Annonaceae have been reported to have potent activity against lymphocytic leukemia in mice (Jolad et al., 1982), anti-malarial activity (Nkunya et al., 1991), it also has the anticarcinogenic and genotoxic effect (Rajeswari et al., 2012), exhibited significant in vitro cytotoxicity against the KB cancer cell line (Véronique Eparvier et al., 2006), has antidiabetic activity (Emordil et al., 2018), has antihemolytic properties (Avaligbe et al., 2012), has antimicrobial activity (Ebi et al., 1999), has high content of phenolic compounds and high antioxydant activity (Kone et.al., 2015).

\section{Materials and methods} Sample collection and preparation

The samples of $U$. chamae (Udagu) leaves, stem back and roots were collected from Oyofo Oghe in Ezeagu Local 
Government Area of Enugu State on 29 ${ }^{\text {th }}$ June, 2019. Oyofo Oghe lies Northwest of Enugu Metropolis. The samples were air dried indoors at room temperature for 21 days and ground into a fine powder with a mechanical grinder.

\section{Successive extraction of active principles for secondary metabolites analysis}

The secondary metabolites in $30 \mathrm{~g}$ of the powdered plant samples (leaves, stem back and roots) were exhaustively extracted with $300 \mathrm{~mL}$ n-hexane in a $500 \mathrm{~mL}$ capacity soxhlet extractor using heating mantle. The extract were concentrated to half the volume and labeled n-hexane extract of $U$. chamae (Udagu) leaves, stem back and roots respectively. The same procedure were repeated with $300 \mathrm{ml}$ of ethyl acetate and methanol and labeled extracts of U. chamae leaves, stem back and roots respectively. (Odebiyi and Sofowara, 1978 and 1979; WHO 2002).

\section{Screening for Secondary metabolites of the plant extracts}

The secondary metabolites in the plant samples were determined using the n-hexane, ethyl acetate and methanol extracts (WHO, 2002; Sofowora, 1982). Standard methods were followed to determine the presence of saponins, glycosides, tannins, flavonoids, steroids, anthracene, alkaloids and volatile oils (WHO, 2002; Sofowora, 1982) etc. in the non-polar n-haxane, slight polar ethyl acetate and strong polar methanol extracts.

\section{Test for saponins}

Two and half milliliter of each extract was vigorously shaken with $10 \mathrm{~mL}$ of water for 2 minutes in a test tube. Then $2 \mathrm{~mL}$ of olive oil was added and observed for persistent frothing and emulsion formation and result recorded (Sofowora, 1993).

\section{Test for saponin glycoside}

Two and half milliliter of mixed Fehling's solutions A and B was added to $2.5 \mathrm{~mL}$ of each extract in a test tube and observed for development of bluish green precipitate and observation recorded (Sofowora, 1993).

\section{Test for steroids and triterpenoids (Libermann Burchaed)}

Two and half milliliter of acetic anhydride was added to $2 \mathrm{~mL}$ of each extract in a test tube and cooled well in ice block. Three milliliter of concentrated sulphric acid was carefully added and a change from violet to blue to green colour was observed and recorded (Sofowora, 1993).

\section{Test for glycosides (General)}

Dilute sulphuric acid $(2.5 \mathrm{~mL})$ was added to $5 \mathrm{ml}$ of each extract in a test tube and boiled for 15 minutes. Then $2 \mathrm{~mL}$ of $10 \% \mathrm{NaOH}$ and $5 \mathrm{ml}$ of mixed Fehling's solution A \& B were added. The formation of brick red precipitate is positive test (Sofowora, 1993).

\section{Test for digital glycosides}

A drop of ferric chloride was added to $2 \mathrm{ml}$ of each extract in a test tube. Two milliliter of glacial acetic acid (glacial means no $\mathrm{H}_{2} \mathrm{O}$ ) and $2 \mathrm{~mL}$ of concentrated sulphuric acid were added. The resulting solutions was observed for the formation of blue layer and the result recorded (Sofowora, 1993).

\section{Test for anthracenes (Born Traggers test)}

Two milliliter of chloroform was added to $2 \mathrm{~mL}$ of each extract and was allowed to separate, to the chloroform layer, $2 \mathrm{~mL}$ of $10 \%$ ammonium solution was added and vigorously shaken and kept to separate, the observation of brick red precipitate is a positive result and recorded (Sofowora, 1993).

\section{Test for tannins}

(a) A mixture of $4 \mathrm{~mL}$ of each extract and $4 \mathrm{~mL}$ of water was stirred very well and three drops of $0.33 \mathrm{~mol} / \mathrm{dm}^{3}$ ferric chloride solution was added and the mixture observed for immediate green colouration and result recorded. (Trease and Evans, 2002).

(b) One milliliter of the extract was treated with few $\mathrm{mL}$ of gelatin solution; a white precipitate is formed revealing the presence of tannins and phenolic compounds (Priyanga et al., 2014).

(c) One milliliter of the extract was treated with few $\mathrm{ml}$ of lead acetate solution. A precipitate production shows the presence of tannins and phenolic compounds (Priyanga et al., 2014).

\section{Test for hydrolysable tannins}

Four milliliter of $10 \%$ ammonia solution was added to $4 \mathrm{~mL}$ of each extract and shaken very well and observed for the formation of an emulsion and the result recorded (Sofowora, 1993). 


\section{Test for Pseudo tannins}

A match stick was dropped into $3 \mathrm{~mL}$ of each extract and two drops of concentrated hydrochloric acid $(\mathrm{HCl})$ was added. The match stick was left undistorted for 5 minutes and observed for a dark purple colouration on it and the result recorded (Sofowora, 1993).

\section{Test for flavonoids}

(a) Magnesium ribbon test (Shinoda Test)

A small quantity of magnesium ribbon was dropped into $2 \mathrm{~mL}$ of each extract and 5 drops of concentrated hydrochloric acid $(\mathrm{HCl})$ added the formation of reddish colouration is positive result and it was recorded (Trease and Evans, 2002).

(b). Alkaline test (NaOH and Acid Test): Addition of increasing amount of $\mathrm{NaOH}$ to the alcoholic extracts shows colouration which decolourises after addition of acid (Biswas and Pandita, 2015).

\section{(c). Lead Acetate test}

To small quantity of residue, $0.5 \mathrm{~mL}$ of $1 \%$ Lead acetate solution was added and observed for yellow colour ppt. formation (Biswas and Pandita, 2015).

\section{Test for resins}

Two milliliter of acetic anhydride was added to $2 \mathrm{~mL}$ of each extract and 2 drops of concentrated surphuric acid added. It was observed for violet colouration and the result recorded (Sofowora, 1993).

\section{Test for alkaloids}

a. Dragendoff's test: Two drops of Dragendoff's reagent was added to $2 \mathrm{~mL}$ of each extract and observed for dip brown precipitate and the result recorded (Sofowora, 1993; Trease and Evans, 1978, 1989).

b. Wagner's test: Two drops of Wagner's reagent was added to $2 \mathrm{~mL}$ of each extract and observed for a dip brown precipitation and the observation recorded (Sofowora, 1993; Trease and Evans, 1978, 1989).

c. Mayer's test: Three drops of Mayer's reagent was added to $2 \mathrm{~mL}$ of each extract and observed for a reddish precipitation or colouration (Sofowora, 1993; Trease and Evans, 1978, 1989).

d. Kraint's test: Two drops of Kraint's reagent was added to $2 \mathrm{~mL}$ of each extract and observed for white precipitate.

Volatile oil test: Six (6) drops of ferric chloride $\left(0.33 \mathrm{~mol} / \mathrm{dm}^{-3}\right)$ solution was added to a mixture of $2 \mathrm{~mL}$ of each extract and $2 \mathrm{~mL}$ of $90 \%(\mathrm{v} / \mathrm{v})$ ethanol was added the resulting mixture was observed for green colouration and the result recorded.

\section{Test for amino acids and proteins}

(a) To $1 \mathrm{~mL}$ of extract, 2 drops of freshly prepared $0.2 \%$ ninhydrin reagent was added and heated. Development of purple color indicates the presence of proteins.

(b) The extract was treated with one $\mathrm{mL}$ of $40 \%$ sodium hydroxide solution and two drops of $1 \%$ copper sulphate reagent. Appearance of violet color indicates the presence of proteins (Priyanga et al., 2014).

\section{Test for carbohydrates}

(a) Fehling's test. The extract was treated with $5 \mathrm{~mL}$ of Fehling's solution (A and B) and kept at boiling water bath for $5 \mathrm{~min}$. Formation of yellow or red color precipitate indicates the presence of reducing sugar (Priyanga et al.,2014).

(b) Benedict's test. To $1 \mathrm{~mL}$ of the extract, added $5 \mathrm{~mL}$ of Benedict's solution and kept at boiling water bath for $5 \mathrm{~min}$. Red, yellow or green precipitate indicates the presence of reducing sugars (Priyanga et al., 2014).

\section{Thin layer chromatographic analysis (TLC)}

Thin layer chromatographic analysis is often used in evaluating medicinal plants material (WHO, 1998). The ascending technique was employed in the TLC analysis. A clean dry chromatographic tank with $50 \mathrm{ml}$ of the running solvent (mobile phase) made-up n-hexane and ethyl acetate (3.1), (3.2) and n-hexane, ethyl acetate and methanol (2.1.1) respectively were used to develop the chromatograms. The spots on the TLC plate after development were visualized in iodine tank and the position of the spots marked with pencil. The retention factor for each spot was calculated for each extract.

\section{DISCUSSION}

Screening for secondary metabolites (Table 1) in the n-hexane (non-polar solvent), ethyl acetate (slightly polar solvent) and methanol (very polar solvent) extracts of $U$. chamae (udagu) plant leaves revealed the presence of saponin, hydrolysable tannins, and alkaloids; saponins and alkaloids and saponins, carbohydrates, alkaloids and tannins respectively in the leaves. In specific terms n-hexane were able to extract saponins, hydrolysable tannins 
and alkaloids while ethyl acetate were able to extract only saponins and alkaloids and methanol were also able to extract saponins, carbohydrates, alkaloids and tannins.

The result of secondary metabolites of $U$. chamae stem back (Udagu) revealed the presence of aponins, saponin glycoside, hydrolysable tannins, flavonoids and alkaloids; Saponins, glycoside, saponin glycoside, hydrolysable tannin, flavonoids and alkaloids, saponins, glycoside, flavonoid, alkaloid and carbohydrate in the nhexane, ethyl acetate and methanol extracts respectively.

The results of the screening for secondary metabolites in the U. chamae (Udagu) plant root (Table 1) revealed that n-hexane extract contains saponins, alkaloids and hydrolysable tannins; the ethyl acetate extract revealed the presence of saponins, tannins, hydrolysible tannins, anthracenes, flavonoids, alkaloids, carbohydrates and protein. While the methanol extract contain saponins, tannins, anthracenes, flavonoid, alkaloids, carbohydrate and protein.

The thin layer chromatographic (TLC) analysis (Table 2) revealed that $U$. chamae (Udagu) plant leaves extracts have varying number of spots (chromatogram) for different solvent system and visualized in iodide tank. The result revealed that the chromatograms developed with n-hexane: ethyl acetate (3:1) solvent system revealed 9 spots, 4 spots and 2 spots for n-hexane, ethyl acetate and methanol extracts respectively. The n-hexane, ethyl acetate (3.2) solvent system revealed the presence of 6 spots, 5 spots and one spot for n-hexane extract, ethyl acetate and methanol extracts respectively. Solvent system n-hexane: ethyl acetate: methanol (2:1:1) could not partition or separate the components in any of the extract.

The TLC analysis (Table 2) revealed that $U$. chamae stem back (Udagu) extracts have varying number of spots (chromatogram) using different solvent system and visualized in iodide tank. The result revealed 7 spots for n-hexane extract, 2 spots for ethyl acetate extract and 2 spots for methanol extract using n-hexane, ethyl acetate $(3: 1)$ solvent system respectively, while n-hexane, ethyl acetate (3.2) solvent system revealed the presence of 6 spots for n-hexane extract, 2 spots for ethyl acetate extract and one for methanol extract respectively. Solvent system n-hexane, ethyl acetate, methanol $(2: 1: 1)$ could not partition or separate the components in any of the extracts.

Table 1: Results of phytochemical screening of Uvaria chamae plant leaves, stem back and roots extracts

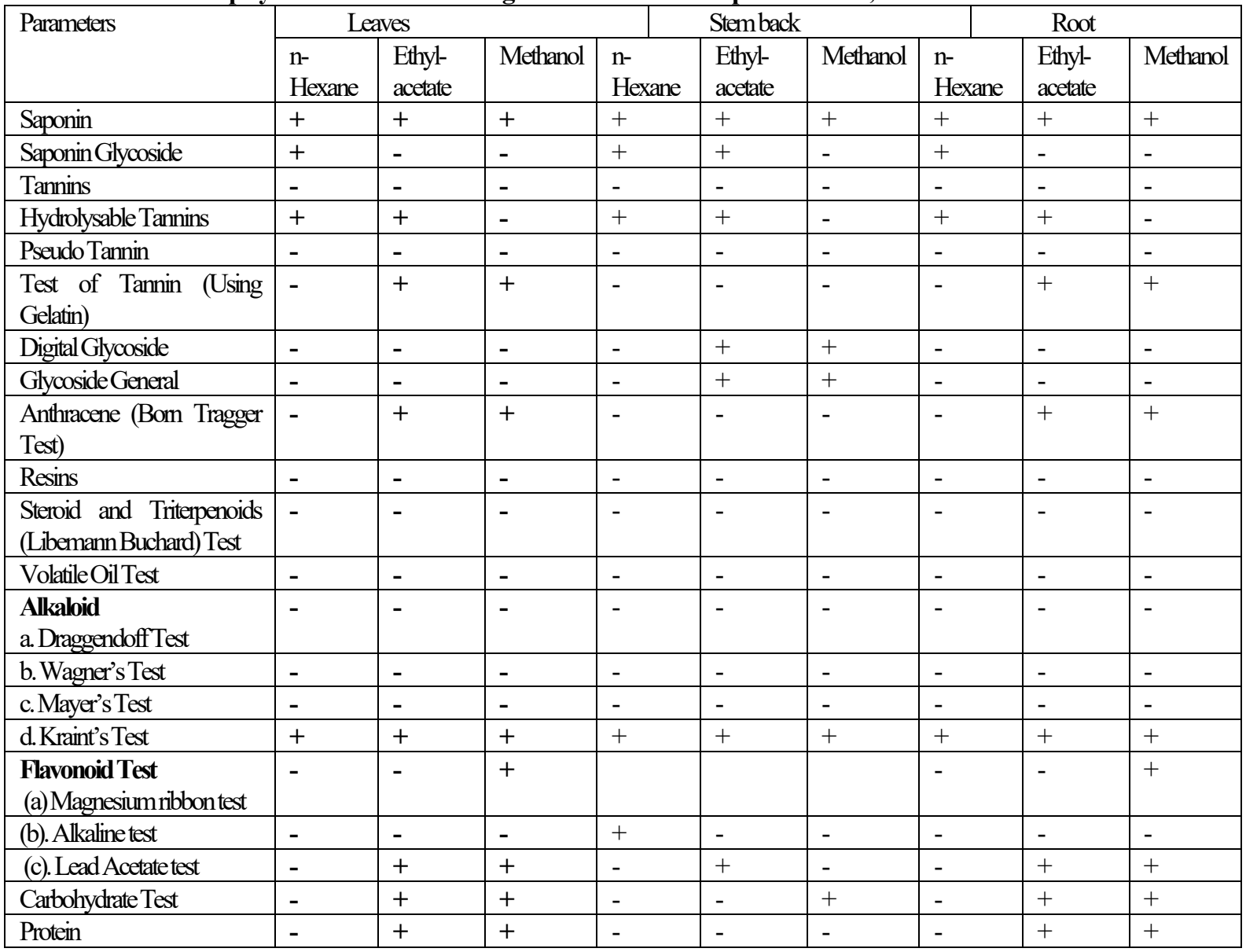


TABLE 2: The number of spots for TLC analysis of Uvaria chamae leaves, stem back and root extracts.

\begin{tabular}{|c|c|c|c|c|c|c|c|c|c|}
\hline \multirow{2}{*}{$\begin{array}{l}\text { Solvent } \\
\text { system }\end{array}$} & \multicolumn{3}{|c|}{ Leaves } & \multicolumn{3}{|c|}{ Stem back } & \multicolumn{3}{|c|}{ Root } \\
\hline & $\begin{array}{l}\mathrm{n}- \\
\text { Hexane }\end{array}$ & $\begin{array}{l}\text { Ethyl- } \\
\text { acetate }\end{array}$ & Methanol & $\begin{array}{l}\mathrm{n}- \\
\text { Hexane }\end{array}$ & $\begin{array}{l}\text { Ethyl- } \\
\text { acetate }\end{array}$ & Methanol & $\begin{array}{l}\mathrm{n}- \\
\text { Hexane }\end{array}$ & $\begin{array}{l}\text { Ethyl- } \\
\text { acetate }\end{array}$ & Methanol \\
\hline $\begin{array}{l}\text { n-hexane, } \\
\text { ethyl acetate } \\
(3: 1)\end{array}$ & 9 & 4 & 2 & 7 & 2 & 2 & 3 & 4 & - \\
\hline $\begin{array}{l}\text { n-hexane, } \\
\text { ethyl acetate } \\
(3: 2)\end{array}$ & 6 & 5 & 1 & 5 & 4 & 1 & 5 & 5 & - \\
\hline $\begin{array}{l}\text { n-hexane, } \\
\text { ethyl acetate, } \\
\text { methanol } \\
(2: 1: 1)\end{array}$ & - & - & - & - & - & - & - & - & - \\
\hline
\end{tabular}

The results of TLC analysis of $U$. chamae plant root (Table 2) shows 3 spots for n-hexane extract, 4 spots for ethyl acetate extract and non for methanol extract using n-hexane and ethyl acetate (3:1) solvent system respectively. For n-hexane and ethyl acetate (3:2) solvent system, n-hexane and ethyl acetate extracts gave 5 spots each and non for methanol. Solvent system n-hexane, ethyl acetate and methanol (2:1:1) gave no spot for n-hexane, ethyl acetate and methanol extracts.

\section{CONCLUSION}

The screening of $n$-hexane extracts for secondary metabolites revealed the presence of saponins, hydrolysable tannins and alkaloids; saponins, saponin glycoside, hydrolysable tannins, flavonoids and alkaloids; and saponins, steroids and triterpenoids, anthracene and hydrolysable tannins for the leaves, stem back and root extracts of $U$. chamae. Ethyl acetate extracts $U$. chamae leaves, stem back and root revealed that saponins and alkaloids; saponins, glycoside, hydrolysable tannin, flavonoids and alkaloids; and saponins and hydrolysable tannins are present, while methanol extracts showed the presence saponins, carbohydrates, alkaloids using Krant's reagent test and tannins; saponins, alkaloids, carbohydrates and protein and saponins, tannins, anthracenes, alkaloids, flavonoids, carbohydrates and protein.

Most of the secondary metabolites present is soluble in non-polar n-hexane solvent showing that majority of them are slightly polar or non-polar in nature. It was observed that n-hexane, ethyl acetate (3:1) solvent system is a better solvent system to separate the phytochemicals present in U. chamae (udagu) plant leaves, stem bark and roots followed by $n$-hexane, ethyl acetate (3:2) while solvent system $n$-hexane, ethyl acetate, methanol (2:1:1) could not partition or separate the components in any of the extracts.

\section{Reference}

1. Hammer, K. A., Carson, C. F. and Riley, T. V. (1999). Antimicrobial activity of essential oils and other plant extracts. J. Appl. Microbiol., 86(6): 985.

2. . Cosa, P., Vlietinck, A.J., Berghe, D.V. and Maes, L. (2006). Anti-infective potential of natural products: How to develop a stronger in vitro 'proof-of-concept'. J. Ethnopharmacol. 106: 290-302.

3. World Health Organization (WHO). (2002). Traditional Medicine - Growing Needs and Potential. WHO Policy Perspectives on Medicines No. 2

4. Kumar P, Kumar M, Teixeira da Silva JA (2013) Pharmacognostic and Phytochemical Investigation of Pongamia pinnata. 2: 634 doi:10.4172/ scientificreports.634

5. Farnsworth, N.R. (1984). The role of medicinal plants in drug development. In: Natural products and Drugs Development, eds. P. Krogsgaard-Larsen, S.B. Christensen, H. Kofod, 8-98. Balliere, Tindall and Cox,London.

6. Nkunya, M., Moshi, M., Joseph, C. and Innocent, E. (1991). In vitro antibacterial activities of extracts and compounds from Uvaria scheffleri. Pharmaceutical Biology, 1744-5116. 42(4): 267-273.

7. Jolad, S.D., Hoffmann, J.J., Schram, K.H. and Cole, J.R. (1982). Uvaricin, a new antitumor agent from Uvaria acuminata (Annonaceae). J. Org. Chem. 47: 3151-3153.

8. Sofowora, A., 1993. Screening Plants for Bioactive Agents: Medicinal Plants and Traditional Medicine in Africa. 2nd Edn., Spectrum Books Ltd., Ibadan, Nigeria, ISBN-13: 9782462195, Pp. 134-156.

9. Stary, F. and Storchova, H. (1991). A Mutual Guide to Medicinal Herbs and Plants. Tiger Books International, UK. P. 44.

10. Trease G.E. and Evans, W.C. (1978). A Text Book of Pharmacognosy. 11th Edn., Bailliere Tindall, London, Pp. 60-75.

11. Trease, G.E. and Evans, W.C. (1989). Pharmacognosy. 13th Edn., ELBS/Bailliere Tindall, London, UK., Pp. $345-346,535-536,772-773$. 
12. Trease, G.E. and Evans, W.C. (2002). Pharmacognosy. 15th Edn., WB Saunders, London, ISBN: 8131200876, P. 406.

13. WHO, 2002. The World Health Report: Reducing Risks, Promoting Healthy Life. World Health Organization, Geneva.

14. Priyanga, S., Hemmalakshmi, S. and Devaki, K. (2014). Comparative Phytochemical Investigation of Leaf, Stem, Flower And Seed Extracts Of Macrotyloma Uniflorum L.. Indo American Journal of Pharm Research.4 (11): 5415-5420.

15. Biswas, S. and Pandita, N. (2015). Phytochemical analysis and chromatographic evaluation of alcoholic extract of Dillenia indica LINN. leaves. International Journal of Pharmaceutical Sciences and Research 6(7): 2799-2812.

16. Chatrou, L. W.; M. D. Pirie; R. H. J. Erkens; T. L. P. Couvreur; K. M. Neubig; J. R. Abbott; J. B. Mols; P. J. M. Maas; R. M. K. Saunders; Mark W. Chase (2012). "A new subfamilial and tribal classification of the pantropical flowering plant family Annonaceae informed by molecular phylogenetics". Botanical Journal of the Linnean Society. 169: S. 4-50.

17. Subramanion, J.L., Yee, S.C., Dharmaraj, S., Subramanian, D., Lachimanan, Y.L., Soundararajan, V., and Sreenivasan, S. (2013). Polyalthia longifolia Sonn: an Ancient Remedy to Explore for Novel Therapeutic Agents. Research Journal of Pharmaceutical, Biological and Chemical Sciences; 4(1):714 -730.

18. Gajalakshmi, S., Vijayalakshmi, S. and Rajeswari, D.V. (2012). Phytochemical and pharmacological properties of Annona muricata: A review. International Journal of Pharmacy and Pharmaceutical Sciences, 4(2): 3-6.

19. Véronique Eparvier, Van Hung Nguyen, Odile Thoison, Françoise Guéritte, Marie-Thérèse Martin and Thierry Sévenet (2006). Cytotoxic Monotetrahydrofuran Acetogenins from Disepalum plagioneurum. Journal of Natural Products 69(9):1289-94.

20. Emordi, J.E., Agbaje, J.E., Oreagba, I. A and Iribhogbe O. I (2018). Antidiabetic Effects of the Ethanolic Root Extract of $U$. chamae P. Beauv (Annonaceae) in Alloxan-Induced Diabetic Rats: A Potential Alternative Treatment for Diabetes Mellitus. Advances in Pharmacological Sciences, 2018: 1-13

21. C. Thierry Avaligbe, Joachim D. Gbenou, D. S. Salomé Kpoviessi, Georges C. Accrombessi, M. Moudachirou and M. Gbeassor (2012). Antihemolytic Properties of Extracts of Six Plants Used in the Traditional Treatment of Sickle Cell Disease in Benin. Journal of Applied Pharmaceutical Science 02 (03): 08-13.

22. G.C EBI ${ }^{a}$ C.J. Ifeanacho ${ }^{a}$ T.N. Kamalu ${ }^{b}$ (1999). Antimicrobial properties of $U$. chamae stem bark. Fitoterapia, 70(6): 621-624.

23. Kone, M., Toure, A., Ouattara, K., Coulibaly, A. (2015). Phytochemical Composition, Antioxidant and Antibacterial Activities of Root of U. chamae P. Beauv. (Annonaceae) Used in Treatment of Dysentery in North of Côte d'Ivoire. International Journal of Pharmacognosy and Phytochemical Research; 7(6); 10471053 . 